\title{
OILS AND FATTY ACIDS ENCAPSULATED IN MICROPARTICLES AS ANTIBACTERIALS: A REVIEW
}

\author{
D.M. Hariyadi ${ }^{\bowtie}$, A. Fitri, T. Purwanti and T. Erawati \\ Department of Pharmaceutical Sciences, Faculty of Pharmacy, Universitas Airlangga, 60115, \\ Surabaya, Indonesia. \\ ${ }^{\square}$ Corresponding Author: dewi-m-h@ff.unair.ac.id
}

\begin{abstract}
Essential oil is a component that can be obtained from plants and animals that have various biological activities such as antibacterial activity for various diseases. Some antibacterial activities come from the unsaturated fatty acid content of essential oils. However, due to the various limitations possessed by essential oils such as volatile, unstable to heat and light, and quickly evaporated, therefore encapsulation of essential oil using a polymer as the wall material can maintain the stability of oils. This review focuses on the encapsulation of oils, lipids, and fatty acids.
\end{abstract}

Keywords: Essential Oils, Encapsulation, Antibacterial, Fatty Acids, Diseases

RASĀYAN J. Chem., Vol. 14, No.3, 2021

\section{INTRODUCTION}

Essential oil from the medicinal plant is a rich source of bioactive components, which has various biological activities for various diseases, including anti-tumor, antioxidant, anti-diabetic, insecticide, and antimicrobial properties. Since a long time ago, essential oil and its bioactive components have been used in the food industry as flavorings and preservatives to enhance taste and stability, prevent food spoilage, and extend the shelf life. ${ }^{1}$

Antibacterial activity has attracted much attention, but due to some of the limitations of this essential oil, such as quickly evaporated, a strong odor, and physically and chemically unstable, an encapsulation technique is developed to solve the problem with this essential oil. ${ }^{2}$ Microencapsulation is a delivery system consisting of two parts (core and shell) that functions as a protective layer consisting of polymers, while the core is an active material such as essential oil. ${ }^{3,4}$

\section{Microencapsulation}

Microencapsulation has been used as a technique that can increase the biological activity and characteristics of essential oil ${ }^{5}$. Microencapsulation is a process in which small and sensitive particles such as fatty acids, also known as the core, are packed into an encapsulation matrix (Fig.-1). ${ }^{5}$ Several encapsulation methods include lyophilization, solvent evaporation, gelation ionic, spray dry, and coacervation.

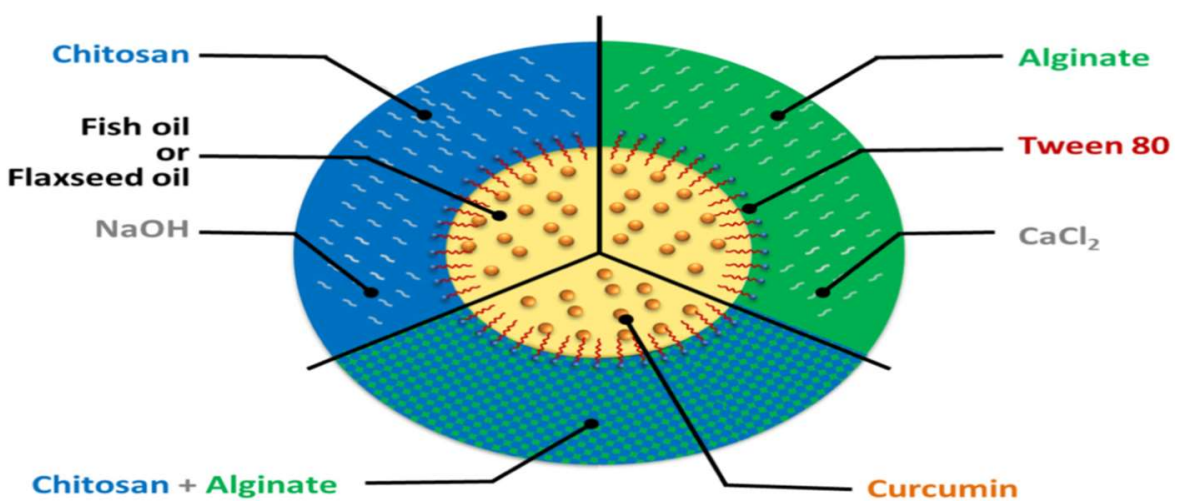

Fig.-1: Illustration of Encapsulation of Omega-3 rich Oil and Curcumin incorporated into a Hydrophilic Polymer: a Combination of Chitosan and Alginate using a $\mathrm{NaOH}$ or $\mathrm{CaCl}_{2} \mathrm{Cross}_{-}$linker ${ }^{5}$. 
RASĀYAN J. Chem.

Vol. 14 | No. 3 |1680-1698| July - September | 2021

\section{Lyophilization}

Lyophilization method is the most widely used method for microencapsulation of essential oil ingredients because it can prevent or prolong the occurrence of evaporation, such as protecting sweet orange essential oil (SOEO) using maltodextrin polymer. ${ }^{3}$

Lyophilization or freeze-drying is a process that removes the water from the product after being frozen and placed in a vacuum which causes ice to change from the solid phase to the vapor phase ${ }^{6}$.

Based on the studies, it is known that particle morphology using the lyophilization method forms irregular size and non-spherical microparticles. Contrarily, with microparticles made using the atomization technique, the particles formed are more spherical and have an irregular size. ${ }^{7}$ This happened because the fluid is frozen in lyophilization process, then water in the form of ice crystals is removed by sublimation, resulting in a porous and brittle structure. ${ }^{8}$

However, this process has several disadvantages, such as it takes a long time, high operational costs and the dry microparticle structure tends to be porous due to the sublimation process. ${ }^{9}$ Therefore, the porous microparticle structure is the most critical factor that must be considered for applying this technique and the high operational costs. ${ }^{10}$

\section{Solvent Evaporation Technique}

Solvent evaporation technique is encapsulation method to efficient most compounds, especially those that are insoluble or have slight solubility in water. ${ }^{4}$

\section{Ionic Gelation}

The ionic gelation method is a simple encapsulation method and does not require high temperature in the process therefore it is suitable for encapsulating volatile materials. ${ }^{7}$ Ionic gelation is a chemical method based on the interaction between polymers with different charges, or between polymers and polycation or polyanion. ${ }^{11}$

The ionic gelation method is based on the ability of polyelectrolytes to form cross-linked bonds in the presence of cross-linker ions forming a hydrogel. This method is prepared by dropping a drug-polymer solution into a solution of a cross linker polyvalent cation. The cation will diffuse into the drug-polymer solution droplets to form a three-dimensional cross-link formation. ${ }^{12}$

The natural or semisynthetic polymers used are alginates, gellan gum, chitosan, and carboxymethyl cellulose. Natural polyelectrolyte contains anion/cation in its chemical structure. Anion/cation will form woven structures with ion counter and induce gelation through cross linking. ${ }^{12}$

\section{Spray Drying}

Spray drying is the oldest encapsulation method and is an economical and flexible process that results in high encapsulation efficiency. ${ }^{13}$ Microparticles with the atomization process show a spherical shape, one of the characteristics of the microparticles produced by this process. However, this process has a drawback, such as microparticles tend to be damaged in the atomizer, which may be caused by air pressure and high temperatures. ${ }^{14}$

The microencapsulation study of echium oil using gelatin and cashew gum / gum arabic as the wall material and synapic acid as a crosslinker dried by spray drying method showed spherical microparticles successfully produced by this process. However, after rehydration showed agglomeration and lost its original form (Fig.-2). This can be explained by the conditions in the drying process that uses high temperature and pressure. ${ }^{14}$

\section{Coacervation Complex}

Microencapsulation through the coacervation complex method is used in the separation of two phases of the biopolymer, which has an opposite charge to the formation of the conservative as a layer and the oilin-water emulsion droplet as the core. The action of the cross linker agent will make the coacervate layer membrane stiffer. ${ }^{15}$

This method is made by dispersing the drug into a polymer solution, then reducing the polymer's solubility by adding a third component to the system. The coacervation process consists of three stages, 
RASĀYAN J. Chem.

Vol. 14 | No. 3 |1680-1698| July - September | 2021

first, separation of the coating polymer solution, second, the adsorption of the coacervate around the drug particles, and third, the compaction of the microspheres. Coacervation is widely used to manufacture water-soluble drug microspheres such as proteins, peptides, and vaccines. ${ }^{16}$ The weakness of this method is that the resulting microspheres tend to aggregate and the scale-up process for production becomes more difficult. These problems can be solved by adjusting the stirring rate, temperature, or adding additives. This method does not use toxic organic solvents and cross-linking as advantages of the retention of the active agent. ${ }^{17}$
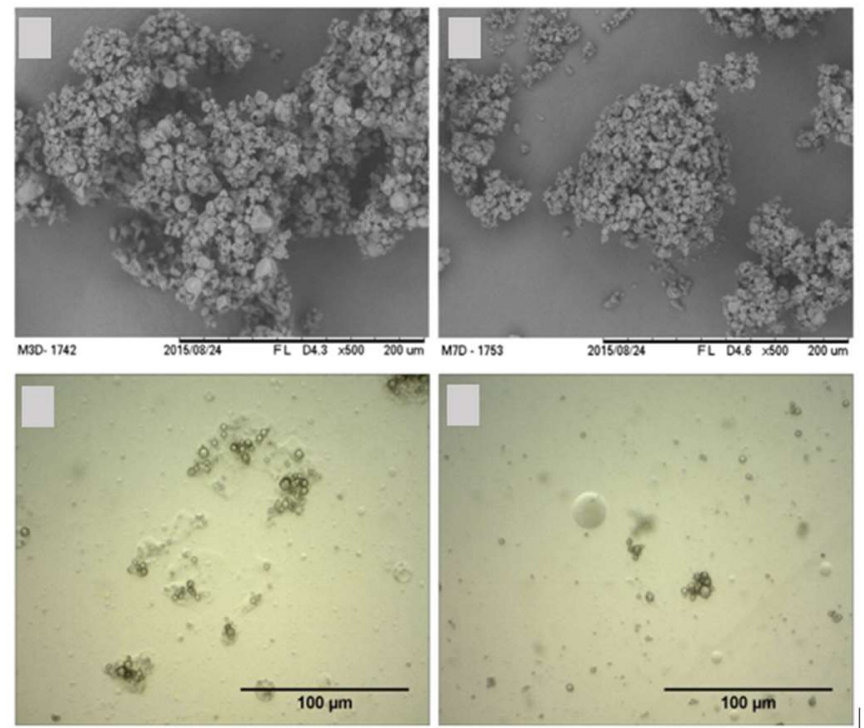

Fig.-2. Optical Microscopy of Echium Oil after atomized and Rehydration ${ }^{14}$

Types of Oils as Antibacterial Agents

Essential oils as antibacterial agents and characterization of microparticles are shown in Table-1 and Table-2.

Table-1: Essential Oils and Antibacterial Activities

\begin{tabular}{|c|c|c|c|c|c|c|}
\hline Oils & Compositions & Functions & $\begin{array}{c}\text { Reasons of } \\
\text { Encapsulation }\end{array}$ & Bacteria & Activities & Ref. \\
\hline $\begin{array}{l}\text { Essential } \\
\text { oil }\end{array}$ & $\begin{array}{l}\text { Cuminaldehyde } \\
\text { Isoeugenol }\end{array}$ & $\begin{array}{l}\text { Antibacterial } \\
\text { Antioxidant }\end{array}$ & $\begin{array}{l}\text { Poor } \\
\text { bioavailability } \\
\text { Difficult to } \\
\text { dissolve in water } \\
\text { Evaporates easily }\end{array}$ & $\begin{array}{l}\text { Staphylococc } \\
\text { us aureus } \\
\text { Eschericia } \\
\text { coli }\end{array}$ & $\begin{array}{l}\text { Each bacteria } \\
\text { decreases after } \\
\text { given essential } \\
\text { oil by } 100 \pm \\
0.6 \% \\
(\text { S.aureus }) \text { and } \\
100 \pm 0.2 \% \\
(\text { E.coli })\end{array}$ & 1 \\
\hline $\begin{array}{l}\text { Star anise } \\
\text { essential oil } \\
\text { (Illicium } \\
\text { verum) }\end{array}$ & $\begin{array}{l}\text { Trans-anethole } \\
\text { After micro- } \\
\text { encapsulated, the } \\
\text { content increases } \\
\text { from } 91.38 \% \text { to } \\
95.36 \%\end{array}$ & $\begin{array}{l}\text { Antioxidant } \\
\text { Antibacterial } \\
\text { liver cancer } \\
\text { prevention }\end{array}$ & $\begin{array}{l}\text { Unstable } \\
\text { Evaporates } \\
\text { quickly }\end{array}$ & $\begin{array}{l}\text { Rhizopus } \\
\text { stolonaifer } \\
\text { Saccharomyc } \\
\text { es cerevisiae } \\
\text { E. coli }\end{array}$ & $\begin{array}{l}\text { Inhibits } \\
\text { Rhizopus } \\
\text { stolonaifer }> \\
\text { Saccharomyce } \\
\text { s cerevisiae> } \\
\text { E. coli }\end{array}$ & 2 \\
\hline $\begin{array}{l}\text { Sweet } \\
\text { orange } \\
\text { essential oil }\end{array}$ & $\begin{array}{l}\text { D-limonene } \\
\text { (96.02\%) } \\
\text { Hydrocarbons }\end{array}$ & $\begin{array}{l}\text { Antibacterial } \\
\text { Antioxidant }\end{array}$ & $\begin{array}{l}\text { Easily oxidized } \\
\text { Evaporates easily }\end{array}$ & $\begin{array}{l}\text { S. aureus } \\
\text { E. coli }\end{array}$ & $\begin{array}{l}\text { Effectively } \\
\text { inhibits } \\
\text { bacteria with } \\
\text { an inhibition } \\
\text { zone between } \\
13.0-18.5 \\
\text { mm }\end{array}$ & 3 \\
\hline $\begin{array}{l}\text { Essential } \\
\text { oil and }\end{array}$ & $\begin{array}{l}\text { Linalool } \\
\text { Anethole trance }\end{array}$ & Antibacterial & $\begin{array}{l}\text { Unstable } \\
\text { Evaporates easily }\end{array}$ & $\begin{array}{l}\text { Staphylococc } \\
\text { us aureus }\end{array}$ & $\begin{array}{l}\text { Inhibits the } \\
\text { growth of }\end{array}$ & 4 \\
\hline
\end{tabular}


RASĀYAN J. Chem.

Vol. 14 | No. 3 |1680-1698| July - September | 2021

\begin{tabular}{|c|c|c|c|c|c|c|}
\hline $\begin{array}{l}\text { other } \\
\text { component } \\
\text { (EOCs) }\end{array}$ & 4-allylanisole & & & $\begin{array}{l}\text { Escherichia } \\
\text { coli }\end{array}$ & $\begin{array}{l}\text { S.aureus and } \\
\text { E. coli }\end{array}$ & \\
\hline $\begin{array}{l}\text { Omega-3 } \\
\text { rich oil }\end{array}$ & Omega-3 rich oil & $\begin{array}{l}\text { Antibacterial } \\
\text { Antioxidant }\end{array}$ & Easily oxidized & $\begin{array}{l}\text { Eschericia } \\
\text { coli } \\
\text { Salmonella } \\
\text { typhimurium } \\
\text { Yersinia } \\
\text { enterolitica } \\
\text { Pseudomonas } \\
\text { aeruginosa } \\
\text { Staphylococc } \\
\text { us aureus } \\
\text { Bacillus } \\
\text { cereus } \\
\text { Listeria } \\
\text { monocytogen } \\
\text { es } \\
\end{array}$ & $\begin{array}{l}\text { Inhibits } \\
\text { bacterial } \\
\text { growth }\end{array}$ & 5 \\
\hline $\begin{array}{l}\text { Thyme } \\
\text { Essential } \\
\text { Oil }\end{array}$ & $\begin{array}{l}\text { Thymol } \\
\text { carvacrol }\end{array}$ & Antibacterial & $\begin{array}{l}\text { Unstable to high } \\
\text { temperatures, } \\
\text { light, and oxygen }\end{array}$ & $\begin{array}{l}\text { Gram positive } \\
\text { bacteria } \\
\text { (S.aureus \& } \\
\text { L. } \\
\text { monocytogen } \\
\text { e) } \\
\text { Gram } \\
\text { negative } \\
\text { bacteria } \\
\text { (E.coli \& } \\
\text { S.enteritidis) } \\
\end{array}$ & $\begin{array}{l}\text { Gram-positive } \\
\text { bacteria show } \\
\text { a larger } \\
\text { inhibition } \\
\text { zone than } \\
\text { gram-negative } \\
\text { bacteria }\end{array}$ & $11-13$ \\
\hline $\begin{array}{l}\text { Mustard } \\
\text { seed } \\
\text { essential oil }\end{array}$ & $\begin{array}{l}\text { Allyl } \\
\text { isothiocyanate } \\
\text { (AITC) } \\
\text { Isothiocyanate } \\
\text { Penetil (PEITC) }\end{array}$ & Antibacterial & $\begin{array}{l}\text { Unstable } \\
\text { Evaporates easily }\end{array}$ & $\begin{array}{l}\text { Gram positive } \\
\text { and negative } \\
\text { bacteria }\end{array}$ & $\begin{array}{l}\text { The inhibition } \\
\text { zone of gram- } \\
\text { positive } \\
\text { bacteria is } \\
\text { greater than } \\
\text { that of gram- } \\
\text { negative } \\
\text { bacteria }\end{array}$ & 15 \\
\hline $\begin{array}{l}\text { Cinnamon } \\
\text { oil }\end{array}$ & $\begin{array}{l}\text { Limonen } \\
\text { Cinnamaldehyde }\end{array}$ & $\begin{array}{l}\text { Flavor } \\
\text { Antibacterial }\end{array}$ & $\begin{array}{l}\text { Evaporates } \\
\text { quickly } \\
\text { Sensitive to light, } \\
\text { heat, and pressure } \\
\text { Difficult to } \\
\text { dissolve } \\
\text { Unstable }\end{array}$ & $\begin{array}{l}\text { E. coli } \\
\text { Y.enteroculiti } \\
\text { ca } \\
\text { B.thermospac } \\
\text { ta } \\
\text { L.monocytoge } \\
\text { nes }\end{array}$ & $\begin{array}{l}\text { Effectively } \\
\text { inhibits at a } \\
\text { concentration } \\
\text { of } 500 \mathrm{ppm} \\
\text { except for } \\
\text { thermospacta } \\
\text { which is at the } \\
\text { concentration } \\
\text { of } 125 \mathrm{ppm}\end{array}$ & 22 \\
\hline $\begin{array}{l}\text { Babchi } \\
\text { essential oil }\end{array}$ & $\begin{array}{l}\text { Bakuchiol } \\
(65.37 \%) \\
2 \text {-phenyl-4- } \\
\text { anilino-6 }(1 \mathrm{H})- \\
\text { pyrimidinone } \\
(1.47 \%), \\
\text { Octadecanoic acid } \\
(1.29 \%), \\
2-5-(2-\text {-methyl } \\
\text { benzoxazole-7-yl) } \\
-\end{array}$ & $\begin{array}{l}\text { Anti-tumor } \\
\text { anti- } \\
\text { inflammatory } \\
\text { Immunomodul } \\
\text { ator } \\
\text { Antioxidant } \\
\text { Antifungal } \\
\text { Antibacterial }\end{array}$ & $\begin{array}{l}\text { Very soluble in } \\
\text { water } \\
\text { Sensitive to light } \\
\text { Very thick } \\
\text { Easily degraded }\end{array}$ & $\begin{array}{l}\text { Staphylococc } \\
\text { us aureus } \\
\text { Eschericia } \\
\text { coli } \\
\text { Pseudomonas } \\
\text { aeruginosa }\end{array}$ & $\begin{array}{l}\text { Inhibition } \\
\text { zone of } \\
\text { Staphylococcu } \\
\text { s aureus } \\
(12.67 \pm 1.49) \\
\text { Eschericia coli } \\
(11.33 \pm 0.98) \\
\\
\text { Pseudomonas } \\
\text { aeruginosa }\end{array}$ & 23 \\
\hline
\end{tabular}


RASĀYAN J. Chem.

Vol. 14 | No. 3 |1680-1698| July - September | 2021

\begin{tabular}{|c|c|c|c|c|c|c|}
\hline & $\begin{array}{l}\text { (1H-pyrazol-3-yl) - } \\
\text { phenol }(1.15 \%), \\
\text { sigmast-5-en-3-ol } \\
(1.04 \%) .\end{array}$ & & & & $(11.67 \pm 0.66)$ & \\
\hline $\begin{array}{l}\text { Clove } \\
\text { essential oil }\end{array}$ & $\begin{array}{l}\text { Eugenol } \\
\beta \text {-caryophyllene } \\
\alpha \text {-humulene }\end{array}$ & $\begin{array}{l}\text { Antioxidant } \\
\text { Antimicrobial }\end{array}$ & $\begin{array}{l}\text { Unstable } \\
\text { Evaporates easily } \\
\text { Difficult to } \\
\text { dissolve in water }\end{array}$ & $\begin{array}{l}\text { S.aureus } \\
\text { E. coli }\end{array}$ & $\begin{array}{l}\text { Inhibits the } \\
\text { growth of } \\
\text { S.aureus and } \\
\text { E. coli }\end{array}$ & 25 \\
\hline Garlic oil & Garlic oil & Antibacterial & $\begin{array}{l}\text { Evaporates easily } \\
\text { Strong scent } \\
\text { Insoluble in water }\end{array}$ & $\begin{array}{l}\text { S. aureus } \\
\text { E. coli }\end{array}$ & $\begin{array}{l}\text { Not show } \\
\text { activity } \\
\text { against } E . \text { coli, } \\
\text { at a } \\
\text { concentration } \\
\text { of } 150-200 \\
\mu \mathrm{g} / \mathrm{ml} \text { it has an } \\
\text { inhibition } \\
\text { zone towards } \\
\text { S.aureus } \\
\text { bacteria }\end{array}$ & 29 \\
\hline $\begin{array}{l}\text { Satureja } \\
\text { Hartensis } \\
\text { essential oil } \\
\text { (SEO) }\end{array}$ & $\begin{array}{l}\text { Carvacrol } \\
(48.51 \%) \\
\gamma \text {-terpinene } \\
(36.63 \%)\end{array}$ & $\begin{array}{l}\text { Antibacterial } \\
\text { Antioxidant }\end{array}$ & Evaporates easily & $\begin{array}{l}\text { E.coli } \\
\text { S. } \\
\text { Typhimurium } \\
\text { S. aureus } \\
\text { L. } \\
\text { monocytogen } \\
\text { es } \\
\end{array}$ & $\begin{array}{l}\text { Inhibits } \\
\text { bacterial } \\
\text { growth }\end{array}$ & $\begin{array}{l}32, \\
55\end{array}$ \\
\hline $\begin{array}{l}\text { Perilla } \\
\text { essential oil }\end{array}$ & $\begin{array}{l}\text { 2-Hexanoylfuran } \\
(17 \%) \\
\text { thymoquinone } \\
(32 \%)\end{array}$ & $\begin{array}{l}\text { Antibacterial } \\
\text { Antioxidant } \\
\text { Anti- } \\
\text { inflammation } \\
\text { Anti-cancer } \\
\end{array}$ & $\begin{array}{l}\text { Sensitive to light } \\
\text { Evaporates easily }\end{array}$ & $\begin{array}{l}\text { Gram positive } \\
\text { and negative } \\
\text { bacteria }\end{array}$ & $\begin{array}{l}\text { Inhibits } \\
\text { bacterial } \\
\text { growth }\end{array}$ & 35 \\
\hline $\begin{array}{l}\text { Pomegranat } \\
\text { e oil }\end{array}$ & $\begin{array}{l}\text { Punicic acid } \\
\text { (ClnA, omega 5) } \\
81.29 \% \\
\text { Linoleic acid } \\
\text { (omega 6) } \\
\text { Linolenic acid } \\
\text { (omega 3) } \\
\text { Eicosapentanoate }\end{array}$ & Antimicrobial & $\begin{array}{l}\text { Unstable } \\
\text { Evaporates easily }\end{array}$ & $\begin{array}{l}\text { Escherichia } \\
\text { coli } \\
\text { Salmonella } \\
\text { typhi } \\
\text { Shigella sonni } \\
\text { Staphylococc } \\
\text { us aureus } \\
\text { Listeria } \\
\text { monocytogen } \\
\text { es } \\
\text { Bacillus } \\
\text { cereus } \\
\end{array}$ & $\begin{array}{l}\text { Gram negative } \\
\text { component is } \\
\text { less sensitive } \\
\text { than gram } \\
\text { positive }\end{array}$ & 56 \\
\hline $\begin{array}{l}\text { Pumpkin } \\
\text { seed oil }\end{array}$ & $\begin{array}{l}\text { Unsaturated fatty } \\
\text { acids }\end{array}$ & Antibacterial & $\begin{array}{l}\text { Evaporates easily } \\
\text { Unstable to } \\
\text { heating }\end{array}$ & $\begin{array}{l}\text { Staphylococc } \\
\text { us aureus }\end{array}$ & $\begin{array}{l}\text { Inhibits } \\
\text { bacterial } \\
\text { growth }\end{array}$ & 57 \\
\hline $\begin{array}{l}\text { Sour cherry } \\
\text { oil }\end{array}$ & $\begin{array}{l}\text { Mono and } \\
\text { polyunsaturated } \\
\text { fatty acids (oleic } \\
\text { acid) }\end{array}$ & Antibacterial & Easily oxidized & $\begin{array}{l}\text { E. coli } \\
\text { S.aureus } \\
\text { P. } \\
\text { Aeruginosa } \\
\text { E.faecalis } \\
\text { A.brasiliensis }\end{array}$ & $\begin{array}{l}\text { Has } \\
\text { antibacterial } \\
\text { activity } \\
\text { against } \\
\text { pathogenic } \\
\text { bacteria } \\
\text { except } E \text {. coli } \\
\text { which is } \\
\text { evaluated } \\
\text { using well- }\end{array}$ & 58 \\
\hline
\end{tabular}


RASĀYAN J. Chem.

Vol. 14 | No. 3 |1680-1698| July - September | 2021

\begin{tabular}{|c|c|c|c|c|c|c|}
\hline & & & & & $\begin{array}{l}\text { diffusion } \\
\text { assay method } \\
\text { Gram negative } \\
\text { bacteria are } \\
\text { more resistant } \\
\text { to antibiotics } \\
\text { because they } \\
\text { have a } \\
\text { distinctive } \\
\text { lipopolysaccha } \\
\text { ride } \\
\text { membrane } \\
\text { layer }\end{array}$ & \\
\hline $\begin{array}{l}\text { Pepper seed } \\
\text { oil (PSO) }\end{array}$ & $\begin{array}{l}\text { Tocopherol } \\
\text { Carotenoids } \\
\text { Kapsaicin } \\
\text { Unsaturated fatty } \\
\text { acids }\end{array}$ & Antibacterial & Easily oxidized & $\begin{array}{l}\text { E. coli } \\
\text { P. aeruginosa } \\
\text { S. aureus } \\
\text { E. faecalis }\end{array}$ & $\begin{array}{l}\text { no } \\
\text { antibacterial } \\
\text { activity except } \\
\text { S.aureus } \\
\text { bacteria = } 13 \\
\text { mm } \\
\text { Encapsulation } \\
\text { increases the } \\
\text { antibacterial } \\
\text { activity of } \\
\text { PSO against } \\
\text { P.aeruginosa } \\
\text { and E. faecalis }\end{array}$ & 59 \\
\hline
\end{tabular}

Table-2: Characterization of Microparticles of Essential Oils

\begin{tabular}{|c|c|c|c|c|}
\hline Oils & Polymers & Methods & Characteristics of Microparticles & Ref. \\
\hline $\begin{array}{l}\text { Star anise } \\
\text { (Illicium verum) }\end{array}$ & $\begin{array}{l}\text { HPCD (Hidroxypropyl- } \beta \text { - } \\
\text { cyclodextrin) } \\
\text { HPCD can increase the } \\
\text { solubility of star anise in } \\
\text { water for the antibacterial } \\
\text { components easily } \\
\text { penetrate the microbial cell } \\
\text { membrane }\end{array}$ & Freeze dry & $\begin{array}{l}\text { The sulfur in the encapsulation } \\
\text { is significantly lower which } \\
\text { results in the bad smell of star } \\
\text { anise essential oil and can be } \\
\text { overcome by the encapsulation } \\
\text { technique. } \\
\text { Encapsulation with HPCD } \\
\text { increases the solubility of star } \\
\text { anise essential oil which results } \\
\text { in antibacterial components that } \\
\text { can easily penetrate the cell } \\
\text { membranes of microorganisms } \\
\text { so as to provide an inhibitory } \\
\text { power towards the growth of } \\
\text { these microorganisms. }\end{array}$ & 2 \\
\hline $\begin{array}{l}\text { Sweet orange } \\
\text { essential oil }\end{array}$ & Maltodextrin and Gel & Lyophilization & $\begin{array}{l}\text { Encapsulation Efficiency; } 74.75 \\
\pm 1.06 \% \\
\text { Thermogravimetry: } \\
\text { SOEO Maltodextrin: } 30 \text { and } 265 \\
{ }^{\circ} \mathrm{C} \\
\text { SOEO: } 30 \text { and } 198^{\circ} \mathrm{C} \\
\text { The thermal degradation of } \\
\text { maltodextrin SOEO is slower } \\
\text { than SOEO }\end{array}$ & 3 \\
\hline Essential oil & $\begin{array}{l}\text { Polylactic acid (PLA) } \\
\text { Poly (methyl methacrylate) } \\
\text { (PMMA) }\end{array}$ & $\begin{array}{l}\text { Solvent } \\
\text { evaporation }\end{array}$ & $\begin{array}{l}\text { Encapsulation efficiency; } 44.5- \\
81.7 \%\end{array}$ & 4 \\
\hline
\end{tabular}


RASĀYAN J. Chem.

Vol. 14 | No. 3 |1680-1698| July - September | 2021

\begin{tabular}{|c|c|c|c|c|}
\hline $\begin{array}{l}\text { Omega-3 rich } \\
\text { oil }\end{array}$ & $\begin{array}{l}\text { Chitosan } \\
\text { Alginate }\end{array}$ & $\begin{array}{l}\text { Nanoemulsion } \\
\text {-in- } \\
\text { microbeads } \\
\text { Oil is made of } \\
\text { nano emulsion } \\
\text { and then } \\
\text { inserted into } \\
\text { the micro- } \\
\text { sized wall } \\
\text { material }\end{array}$ & $\begin{array}{l}\text { - Encapsulation efficiency; } 83- \\
99 \% \\
\text { - Oil derived from plant seeds: } \\
\text { The first peak appears at } \\
\text { temperature approaching } 200{ }^{\circ} \mathrm{C} \\
\text { (weight loss of } 8.09-15.89 \% \text { ) } \\
\text { The second peak appears at } \\
\text { temperatures of } 200-390^{\circ} \mathrm{C} \\
\text { (weight loss of } 12.62-39.14 \% \text { ) } \\
\text { The third peak is at } 390-590^{\circ} \mathrm{C} \\
(14.99-22.34 \% \text { ) }\end{array}$ & 5 \\
\hline $\begin{array}{l}\text { Thyme essential } \\
\text { oil }\end{array}$ & $\begin{array}{l}\text { Casein } \\
\text { maltodextrin }\end{array}$ & Spray dry & $\begin{array}{l}\text { - Encapsulation Efficiency; } \\
88.9 \% \\
\text { - Thermogravimetric: } \\
\text { TEO = close to } 200^{\circ} \mathrm{C} \\
\text { TEO encapsulation }>300^{\circ} \mathrm{C}\end{array}$ & 13 \\
\hline $\begin{array}{l}\text { Mustard seed } \\
\text { essential oil }\end{array}$ & $\begin{array}{l}\text { Gelatin } \\
\text { Arabic gum }\end{array}$ & $\begin{array}{l}\text { Coacervation } \\
\text { complex }\end{array}$ & Decompostion begins at $250{ }^{\circ} \mathrm{C}$ & 15 \\
\hline $\begin{array}{l}\text { Satureja } \\
\text { Hartensis } \\
\text { essential oil } \\
\text { (SEO) }\end{array}$ & Alginate & Ionic gelation & $\begin{array}{l}\text { - Loading capacity; } \\
20.27 \pm 0.94 \% \text { - } 26.13 \pm 0.71 \% \\
\text { - Encapsulation Efficiency: } \\
52.40 \pm 0.65 \% \text { - } 66.37 \pm 1.00 \\
\text { - Thermogravimetric: } \\
\text { SEO without encapsulation: } \\
128-178^{\circ} \mathrm{C} \\
\text { SEO with encapsulation: } 178- \\
189^{\circ} \mathrm{C}\end{array}$ & 32 \\
\hline $\begin{array}{l}\text { Perilla essential } \\
\text { oil }\end{array}$ & Sodium alginate & Ionic gelation & $\begin{array}{l}\text { - Encapsulation efficiency: } 33- \\
57 \% \text {, where the highest EE is } \\
\text { obtained with a PEO } \\
\text { concentration of } 2 \% \\
\text { - Loading capacity: } 25-36 \% \\
\text { with a maximum loading } \\
\text { capacity that is also obtained } \\
\text { with a PEO concentration of } \\
2 \% \\
\text { - The increase in PEO } \\
\text { concentration does not make } \\
\text { EE and LC increase, but it is } \\
\text { probably due to the saturation } \\
\text { of EO that enters the sodium } \\
\text { alginate particles. }\end{array}$ & 35 \\
\hline $\begin{array}{l}\text { Pepper seed oil } \\
\text { (PSO) }\end{array}$ & $\begin{array}{l}\text { Arabic gum } \\
\text { Maltodextrin }\end{array}$ & Spray dry & $\begin{array}{l}\text { - Yield is } 34.99-57.77 \% \\
\text { The increase of maltodextrin } \\
\text { concentration in the emulsion } \\
\text { increases the yield of } \\
\text { microparticles } \\
\text { The drying temperature has a } \\
\text { good effect on the microparticle } \\
\text { yield, but has a bad effect on the } \\
\text { oil content of the emulsion. } \\
\text { - Encapsulation efficiency: } \\
67.45-87.14 \% \\
\text { A higher inlet temperature } \\
\text { decreases the presence of } \\
\text { surface oil, thereby increasing } \\
\text { the high encapsulation }\end{array}$ & 59 \\
\hline
\end{tabular}


RASĀYAN J. Chem.

Vol. 14 | No. 3 |1680-1698| July - September | 2021

\begin{tabular}{|c|c|c|c|c|}
\hline & & & $\begin{array}{l}\text { efficiency } \\
\text { - Morphology } \\
\text { The particle size distribution } \\
\text { varies from } 0.5-80 \mu \mathrm{m}\end{array}$ & \\
\hline \multirow[t]{2}{*}{ Fish oil } & $\begin{array}{l}\text { casein-pectin and gum } \\
1687 \text { teara, maltodextrin }\end{array}$ & $\begin{array}{l}\text { Coacervation } \\
\text { complex, } \\
\text { spray drying } \\
\text { (casein-pectin- } \\
\text { maltodextrin } \\
\text { microparticles } \\
\text { ) } \\
\text { Suspension, } \\
\text { spray drying } \\
\text { (gum } \\
\text { 1687teara- } \\
\text { maltodextrin) }\end{array}$ & $\begin{array}{l}\text { - EE Arabic gum } \\
\text { microparticles: } 51.2-56.79 \% \text {; } \\
\text { Casein pectin microparticles: } \\
64.74-67.89 \% ; 10 \% \text { higher } \\
\text { than Arabic gum } \\
\text { microparticles } \\
\text { - Microencapsulation with the } \\
\text { coacervation complex method } \\
\text { is an efficient method } \\
\text { The percentage of solid used is } \\
\text { 30\% because the high } \\
\text { concentration of solid can } \\
\text { reduce oil migration to the } \\
\text { capsule surface and at this } \\
\text { concentration the polymer is not } \\
\text { too viscous so that it does not } \\
\text { inhibit the atomization process } \\
\text { (not clogged at the nozzle) }\end{array}$ & 60 \\
\hline & Hydroxypropyl cell ulose & $\begin{array}{l}\text { conventional } \\
\text { spray drying } \\
\text { the ratio of FO } \\
\text { and HPC used } \\
\text { varies up to a } \\
\text { ratio of } 1: 4.3 \\
\text { the solvents } \\
\text { used to } \\
\text { disperse the } \\
\text { HPC are also } \\
\text { different } \\
\text { (methanol, } \\
\text { ethanol, and } \\
\text { acetone) }\end{array}$ & $\begin{array}{l}\text { - Encapsulation using } \\
\text { FO/acetone has the lowest } \\
\text { percentage of oil on the } \\
\text { surface, followed by ethanol, } \\
\text { methanol, and water } \\
\text { - The use of solvents does not } \\
\text { affect the release of FO }\end{array}$ & 61 \\
\hline Patchouli oil & maltodextrin & $\begin{array}{l}\text { Spray dry } \\
\text { Flow rate } 300 \\
\mathrm{~mL} / \mathrm{min} \\
\text { Inlet } \\
\text { temperature } \\
110^{\circ} \mathrm{C} \\
\text { Outlet } \\
\text { temperature } \\
68^{\circ} \mathrm{C}\end{array}$ & $\begin{array}{l}\text { The smaller the maltodextrin } \\
\text { used, the microparticles are } \\
\text { formed, the more spherical it is } \\
\text { and there is no agglomeration }\end{array}$ & 62 \\
\hline
\end{tabular}

\section{Star Anise Essential Oil (SAEO)}

Star anise (Illicium verum) is a plant in the Magnoliaceae family. This fruit is a spice found in Southeast China. Their usages include as an antioxidant, antibacterial, prevention of liver cancer, and insect repellent. This oil is obtained from star anise fruit ranging from $3-3.5 \%$ in fresh fruit and $>8 \%$ in dry fruit obtained by steam distillation. Due to its biological activity, star anise essential oil is used in food and medicine. This star anise essential oil is also used in baked food, candy, alcoholic beverages, and soda. It can also be used to relieve the inflammatory response, as medicinal tea flavor, and as cough medicine mixture. ${ }^{2}$

Gas Chromatography-Mass Spectrometry (GC-MS) analysis is method to identify the essential oil components. A study on star anise essential oil has been conducted by comparing star anise essential oil 
RASĀYAN J. Chem.

Vol. 14 | No. 3 |1680-1698| July - September | 2021

composition before being encapsulated with after being encapsulated. GC-MS identifies 13 main components. The main components of SAEO before it is encapsulated are trans-anethole (91\%), then followed by estragole (2.5\%), and trans-foeniculin (2\%). In contrast, after encapsulation, trans-anethole $(95 \%)$, followed by estragole $(2.23 \%)$, and trans-foeniculin $(0.91 \%)$ are obtained. Based on the data above, it is known that the contents contain no changes in the essential oil before and after encapsulation. ${ }^{2}$ The contents obtained after the encapsulated star anise essential oil decrease, except for trans/cisanethole, indicate that these two components are suitable when encapsulated in hydroxypropyl- $\beta$ cyclodextrin (HPCD). This decrease/change is due to differences in structure and polarity in the molecules that make up star anise essential oil and different HPCD encapsulation. The effect of HPCD encapsulation on essential oil may be closely related to the molecular structure of the essential oil. ${ }^{2}$

Star anise essential oil has antibacterial activity against Staphylococcus aureus and Escherichia coli. However, the inhibition of oil only was lower than encapsulated star anise essential oil. ${ }^{18}$

\section{Sweet Orange Essential Oil (SOEO)}

SOEO is obtained from orange fruits. Orange fruits have good economic value with their production mainly used to manufacture juices that contain ingredients that have biological activity. Orange fruit oil can be used in agriculture, pharmaceuticals, cosmetics, and the food industry. Orange oil contains Dlimonene, a large amount of monoterpene hydrocarbons, as well as small amounts of oxygenated monoterpenoids and sesquiterpenes. ${ }^{3}$

In a study conducted by JSF de Araújo et al, the polymers used as wall material for the microspheres are SO1 (Maltodextrin only); SO2 (Maltodectrin : gel 2:1), and SO3 (Maltodextrin : gel 1:1). Those three formulas have an inhibition zone against the growth of Staphylococcus aureus and Escherichia coli bacteria of 13.0-18.5 mm. Based on the antibacterial activity test against the sweet orange essential oil microsphere, it can be said that the microencapsulated SOEO is able to diffuse through the culture medium. ${ }^{3}$

\section{Omega-3 Rich Oil}

Fish oil is the most important source of omega-3 unsaturated fatty acids such as eicosapentanoic acid (EPA) and docosahexanoic acid (DHA). These two components can reduce the risk of certain chronic diseases such as inflammation, cardiovascular, immune response disorders and mental disorders. Some of the shortcomings of these unsaturated fatty acids are the high lipophilic molecules that will cause difficulty in absorption and poor bioavailability. In addition, unsaturated fatty acids are also easily oxidized, which will cause reduced nutritional value and the formation of toxic products. ${ }^{19}$ Microencapsulation can prevent omega-3 fatty acids from oxidizing and extend the shelf life (expired date); therefore, it can be a solution to maintain the stability of the oil. ${ }^{5}$

The antibacterial activity of omega-3 rich oil (which comes from plants and fish) is carried out by the agar diffusion method (well). The result shows that omega-3 rich oil derived from fish has more significant antibacterial activity than that from plants. This study also found that omega-3 rich oil (derived from fish), which is included in the alginate polymer and added with curcumin as an antioxidant, showed grampositive and gram-negative antibacterial activities. Fish oil incorporated into alginate particles showed better antibacterial activity than fish oil loaded in chitosan particles and chitosan-alginate combination. ${ }^{5}$

\section{Thyme Essential Oil (TEO)}

Thyme essential oil (Thymus vulgaris) contains thymol and carvacrol, phenols which have antibacterial activity. ${ }^{20}$ However, specific problems such as volatility, difficulty dissolving in water can prevent this oil from being dispersed in the food matrix. To solve this problem, thyme essential oil can be encapsulated to increase bioactivity. ${ }^{21}$ Research conducted by Radunz et al states that there are differences in the chemical compound components found in thyme essential oil without encapsulation with encapsulated TEO with the main components of thymol and carvacrol, which also shows that the contents of these two components increase after the encapsulation process. This can be due to the formation of a hydrogen bond between the hydroxyl groups and the active site of the protein molecule, thereby increasing volatile retention during encapsulation. ${ }^{13}$ The yield obtained from TEO microencapsulation process is relatively low, which is between $60.2-62.3 \%$. This is due to the emulsion loss during the removal of the emulsion 
from the container and syringe. Besides that, it is also during the drop dripping process through the syringe. ${ }^{11}$

Several oils encapsulated in polymer show inhibitory and bactericidal effects, for examples Thyme essential oil with encapsulation has an inhibitory and bactericidal effect against Salmonella typhimurium, Listeria monocytogenes, Staphylococcus aureus, and Escherichia coli bacteria with a minimum inhibition zone of $0.1 \mathrm{mg} / \mathrm{ml}$, which can be said that TEO is a potential antimicrobial agent. ${ }^{13}$

\section{Cinnamon Essential Oil (CEO)}

In this study, the kinetics of CEO encapsulation in cyclodextrin nanosponge (CD-NS) in a polar solvent such as ethanol incubated for 96 hours is performed. The equilibrium point is reached at an incubation time of 24 hours and after that time, it does not show significant cinnamaldehyde entrapped in CD-NS. ${ }^{22}$ In antibacterial testing against CEO, minimum inhibitory concentration (MIC) is obtained for grampositive bacteria of B. thermospacta and L.monocytogenes and gram-negative bacteria of E.coli and $Y$. enterolitica. Both CEO without encapsulation and CEO with encapsulation can inhibit bacterial growth. For its working action, CEO with encapsulation does not affect the mechanism of action against bacterial cells, which means that the bactericidal and bacteriostatic effects of the CEO are still maintained. ${ }^{22}$

\section{Babchi Essential Oil}

Babchi essential oil is obtained from the extraction of Psoralea caryfolia L. Dried fruit of P.caryfolia is known as traditional Chinese medicine registered in the Chinese Famakopea. This herb is also reported to be used to treat skin damage such as leukoderma, leprosy, and psoriasis. ${ }^{23}$ Encapsulation is a method to overcome this problem because it is easy to be photodegradable at a constant rate. After the Babchi essential oil was entrapped in the nanoparticles, a photodegradation test was carried out and a reduction in the rate of degradation was obtained. ${ }^{24}$

\section{Clove Essential Oil}

Clove oil comes from Eugenia caryophylata plant from the Myrtaceae family that is used as a herbal plant. Clove oil contains eugenol and its derivatives. ${ }^{25}$ The phenol content in this oil has antibacterial activity that can inhibit bacteria growth, which works by poisoning the cytoplasm, damaging and penetrating bacterial cell walls ${ }^{26}$. The clove essential oil microparticles were successfully obtained by the spray dry method, which increased their solubility and stability. ${ }^{27}$ Clove essential oil microparticles using maltodextrin with a ratio of 1: 8 showed the microparticles were round but slightly wrinkled. This causes the oil not wholly to fill the wall material. ${ }^{28}$

\section{Garlic Essential Oil}

Garlic is a natural ingredient used throughout the world for cooking, so it has attracted researchers to conduct further research. The main components of this garlic oil are diallyl sulfide (DAS) 5.69\%, diallyl disulfide (DADS) 60.12\%, and diallyl trisulfide (DATS) $14.18 \%$ which have many pharmacological activities. $^{29,30}$ The method used affects the content of garlic essential oil. The Clevenger laboratory hydrodistillation method obtained DADS and DATS of $20.8 \%$ and $33.4 \%$ where this content was not significantly different from the results obtained from industrial steam distillation, which gave an increase in the content of DAS and DADS. ${ }^{31}$

\section{Satureja hortensis Essential Oil (SEO)}

Saturejo hortensis is a medicinal plant belonging to the Lamiaceae family, widely used in the Mediterranean area as a spice and traditional medicinal ingredients. Besides that, it is also known for its biological activity as antibacterial and antioxidant due to its high phenolic content in this plant. ${ }^{32}$

This essential oil also has activity against gram-positive and gram-negative bacteria in the order of $P$. aeruginosa $>E$. coli $=S$. typhimurium $>$ S.aureus $>$ L. monocytogenes, which is strongly suspected to come from the content of carvacrol which is the main ingredient in SEO with $48.51 \%$ content. In addition, SEO also contains $\gamma$-terpinene, $\rho$-cymene, terpinolene, $\alpha$-terpinene, $\alpha$-pinene, and $\alpha$-thujene compounds. The place to grow affects the compound content contained in SEO. SEO originating from Egypt does not contain thymol which is inversely proportional to SEO from French. ${ }^{33}$ 
Storage conditions such as temperature, storage time and interaction of content also play an essential role in maintaining the quality and quantity of active compounds. The carvacrol content stored in the freezer was more stable than SEO stored in the refrigerator and at room temperature, respectively. ${ }^{34}$

\section{Perilla Essential Oil (PEO)}

Perilla frustescens (L.) Britt is a seasonal aromatic plant widely used in Asian countries such as China, Japan, North Korea, and India for cooking and medicine. PEO consists of a mixture of volatile compounds with antioxidant, antimicrobial, anti-inflammatory, insecticidal, anticancer, and antidepressant activities. ${ }^{35}$

\section{Encapsulation of Oils in Polymer}

A schematic overview of the encapsulation of the oils in the polymer is shown in Fig.-1.

\section{Evaluation of Essential Oil Encapsulation \\ Morphology}

The difference in morphology and capsule diameter is influenced by the characteristics of encapsulation and wall material used ${ }^{13}$. Encapsulation of Pimenta dioica essential oil in chitosan microparticles protected with $\kappa$-carrageenan showed irregular microparticles (Fig.-3a). At higher $\kappa$-carrageenan concentrations, the consistency of the gel formed was higher and would form irregular aggregates of microparticles (Fig.-3b). Whereas microparticles using glutaraldehyde as a crosslinker showed irregular microparticles with a hard and rigid surface full of holes and cracks (Fig.-3c, d) ${ }^{36}$.

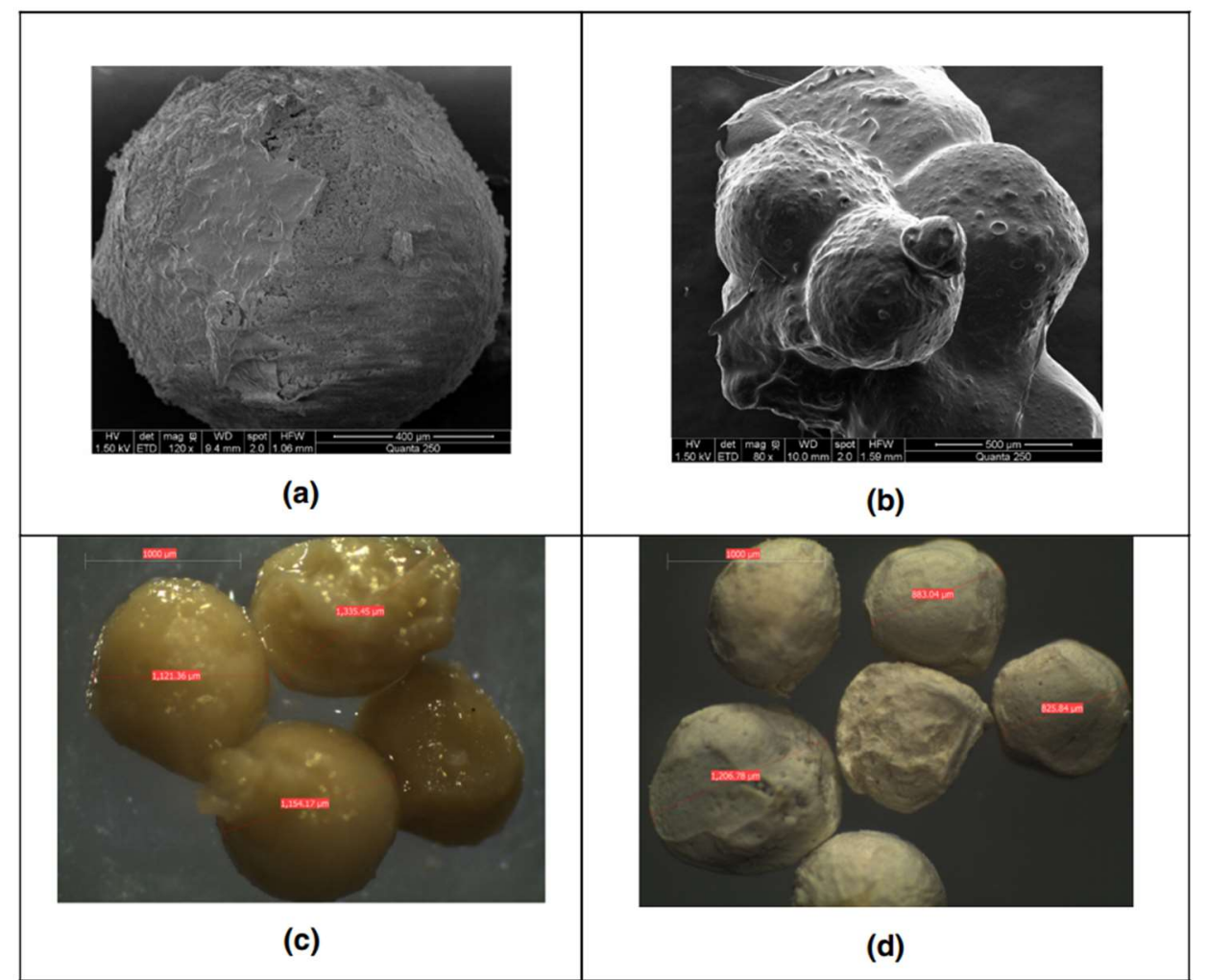

Fig.-3: Morphology of Pimenta dioica Essential Oil-Chitosan Microparticle covered with $\kappa$-Carrageenan ${ }^{36}$

\section{Microparticle Size}

Microencapsulation of essential oil with polylactic acid (PLA) and Polimethyl methacrylate (PMMA) with particle sizes using PLA polymers ranging from 1.5-9.5 $\mu \mathrm{m}$ has a polydispersity index (PDI) of 1.62.7 which indicates that these microparticles have a broad particle size distribution due to PDI in this study, that is $>0.7^{4}$. The ratio of the mixture used has little effect on microsphere size, although it does not have a significantly different dispersity. ${ }^{4}$ Microparticles of Pimenta dioica essential oil using chitosan, 
which $\kappa$-carrageenan protects, have an average diameter of $1224 \pm 6.56 \mu \mathrm{m}$. Meanwhile, microparticles using a crosslinker obtained a lower average diameter. The size of these oil microparticles decreases along with the increase in chitosan, which is used as a result of tensioactive chitosan reducing the interfacial tension to support the formation of microparticles. ${ }^{36}$

\section{Encapsulation Efficiency}

According to Benavides et al, the increase of TEO amount decreases encapsulation efficiency in the microsphere with alginate as the wall material. This can be explained due to the limitation of the microsphere in accommodating oil. When the oil concentration increases, the oil will stick a lot or be close to the surface of the microsphere; therefore, when drying, this oil will be lost due to its volatile nature, which will reduce the encapsulation efficiency. 2\% TEO, which is distributed at a speed of 18000 $\mathrm{rpm}$ has an encapsulation efficiency of 85\%. ${ }^{11}$ In addition, another factor that can affect the encapsulation efficiency is the polymers used, such as the study using casein and maltodextrin, which results in an encapsulation efficiency of $88.9 \%$. The amount of encapsulation efficiency obtained is probably because the spray dry method can minimize mechanical damage compared to other methods and the oil component's affinity with a higher wall material. ${ }^{13}$

High encapsulation efficiency is also obtained in the microencapsulation of linalool using polylactic acid (PLA) polymer, which is $81.7 \%$ because linalool has a larger surface area polar topology ${ }^{10}$. The polarity of the essential oil and polymers is an important factor in the absorption process because those absorbed easily are those with the same polarity (polar PLA, polar linalool). ${ }^{4}$

\section{Thermogravimetric Analysis (TG)}

Thermogravimetric analysis (TG) is used to evaluate the thermal properties of the microsphere about mass loss compared to its single component (without microencapsulation). SOEO without microencapsulation shows thermal degradation at temperatures between $30^{\circ} \mathrm{C}$ and $198^{\circ} \mathrm{C}$, which means that thermal degradation occurs faster, where the most significant degradation occurs at a temperature of $98.61^{\circ} \mathrm{C}$ with almost $90 \%$ of mass loss. In contrast, SOEO microspheres using maltodextrin show slower thermal degradation. The degradation of SOEO without microencapsulation starts at $60.44^{\circ} \mathrm{C}$, while in SOEO microsphere the temperature is $>250^{\circ} \mathrm{C} .{ }^{23}$ This is also the case with the encapsulation of thyme essential oil (TEO) without encapsulation, showing mass loss at temperatures approaching $200^{\circ} \mathrm{C}$ while TEO is encapsulated at a temperature of $>300^{\circ} \mathrm{C}$ which states that the encapsulation process increases the thermal stability of the essential oil. ${ }^{12}$ In Satureja hortensis essential oil (SEO), an increase in temperature of decomposition occurs after SEO is encapsulated with alginate polymer. From the explanation above, it can be concluded that encapsulation of essential oils can increase the thermal stability of essential oils. ${ }^{32}$ Mustard seed essential oil encapsulated with gelatin and genipin as a crosslinker agent decomposes at a temperature of $250^{\circ} \mathrm{C}$. This is because, under neutral and weak alkaline environmental conditions, genipin as a crosslinker and amino group polymers such as gelatin will form a cross-linked network. ${ }^{22}$ On the other hand, in strongly alkaline conditions, the microparticle stability of mustard seed essential oil is reduced. This may be due to a strong alkaline condition that makes the microparticles prone to swelling. ${ }^{15}$

\section{Differential Scanning Calorimetry (DSC)}

Based on the analysis using DSC, it is known that SOEO without microencapsulation undergoes an endothermic process at temperatures between $30{ }^{\circ} \mathrm{C}$ and $87.8{ }^{\circ} \mathrm{C}$, in which it is characterized at this temperature that SOEO experiences evaporation and at a temperature of $126.4{ }^{\circ} \mathrm{C}$ oxidative degradations begins to occur. In wall material using maltodextrin polymer, the endothermic process occurs at a temperature of $92.5^{\circ} \mathrm{C}$ which means that the system will lose moisture at that temperature, which will also be followed by the loss of SOEO from the system. The use of the microencapsulation technique effectively prolongs the thermal degradation time and the evaporation time of SOEO. ${ }^{3}$

\section{Fatty acid}

Oils contain fatty acids and their antibacterial activities are demonstrated in Table-3. Fatty acid is a molecule that is usually found attached to other compounds such as sugar, glycerol, or phosphate, which 
RASĀYAN J. Chem.

Vol. 14 | No. 3 |1680-1698| July - September | 2021

is the main group forming lipid. Lipid is an important component of cell structure, for example, for cell membrane, which is the main component of phospholipid. ${ }^{37}$

Table-3: Oils containing Active Fatty Acid as Antibacterial

\begin{tabular}{|c|c|c|c|}
\hline Oils & Compositions & Antibacterial Activities & References \\
\hline $\begin{array}{l}\text { Crotalaria } \\
\text { juncea seed oil } \\
\text { (CJSPE) }\end{array}$ & $\begin{array}{l}\text { Linoleic acid } 62 \% \\
\text { Palmitic acid } 18 \% \\
\text { Stearic acid } 10 \%\end{array}$ & $\begin{array}{l}\text { Inhibition zone against bacteria: } \\
\text { S. aureus }(18 \mathrm{~mm}) \\
\text { E. coli }(17 \mathrm{~mm}) \\
\text { K. pneumonia }(16 \mathrm{~mm}) \\
\text { P. aeruginosa }(8 \mathrm{~mm}) \\
\text { S. flexneri }(16 \mathrm{~mm}) \\
\text { V. cholera }(14 \mathrm{~mm}) \\
\end{array}$ & 39 \\
\hline $\begin{array}{l}\text { Tamarindus } \\
\text { indica seed oil }\end{array}$ & $\begin{array}{l}\text { Asam lemak jenuh: } \\
\text { Asam kaprilat } 12.66 \% \\
\text { Asam laurat } 25.18 \% \\
\text { Asam lemak tak jenuh : } \\
\text { Asam linoleat }(21.91- \\
38.68 \%) \\
\text { Asam oleat }(17.76 \%) \\
\end{array}$ & $\begin{array}{l}\text { Inhibition zone with acetone extract: } \\
\text { Escherichia coli } 7.9 \mathrm{~mm} \\
\text { Staphylococcus epidermidis } 7.1 \mathrm{~mm} \\
\text { No antibacterial activity at n-hexane and } \\
\text { DMSO extract }\end{array}$ & 40 \\
\hline $\begin{array}{l}\text { Crotalaria } \\
\text { pallida leaf oil }\end{array}$ & $\begin{array}{l}\text { Linolenic acid (34.06\%) } \\
\text { Palmitic acid }(24.47 \%)\end{array}$ & $\begin{array}{l}\text { Minimum inhibitory and inhibition zone } \\
\text { diameter: } \\
\text { B. subtilis }(80 \mu \mathrm{g} / \mathrm{ml} \text { and } 15 \mathrm{~mm}) \\
\text { E. coli }(10 \mu \mathrm{g} / \mathrm{ml} \text { and } 18 \mathrm{~mm}) \\
\text { Acinetobacter junii }(10 \mu \mathrm{g} / \mathrm{ml} \text { and } 18 \mathrm{~mm})\end{array}$ & 43 \\
\hline $\begin{array}{l}\text { Mastic tree oil } \\
\text { (Pistacia } \\
\text { lentiscus } \text { L.) }\end{array}$ & $\begin{array}{l}\text { Oleic acid }>56 \% \\
\text { Palmitic acid 27\% } \\
\text { Linoleic acid 16\% }\end{array}$ & $\begin{array}{l}\text { The pressing methode and growing sites in } \\
\text { Byzerte has abtibacterial activity against } \\
\text { Clostridium perfringens with inhibition } \\
\text { zone } 13 \mathrm{~mm} \\
\text { There is no antibacterial activity against } \\
\text { E.coli and S.typhimurium }\end{array}$ & 44 \\
\hline $\begin{array}{l}\text { Swietenia } \\
\text { macrophylla } \\
\text { seed oil }\end{array}$ & $\begin{array}{l}\text { Linoleic acid } 37.5-39.21 \% \\
\text { Oleic acid } 18.82-22.03 \% \\
\text { Stearic acid } 16.57-17.65 \% \\
\text { Palmitic acid } 14.62-15.47 \\
\%\end{array}$ & $\begin{array}{l}\text { Inhibition zone of seed oil at concentration } \\
10-1000 \mu \mathrm{g} / \mathrm{mL} \text { : } \\
\text { S. aureus } 5-11 \mathrm{~mm} \\
\text { S. typhimurium } 4-20 \mathrm{~mm} \\
\text { P.aeruginosa } 5-11 \mathrm{~mm} \\
\text { No activity against E.coli }\end{array}$ & 45 \\
\hline $\begin{array}{l}\text { Virgin Coconut } \\
\text { Oil }\end{array}$ & $\begin{array}{l}\text { Lauric acid } \\
\text { Caprylic acid } \\
\text { Capric acid }\end{array}$ & $\begin{array}{l}\text { 1.2\% VCO has been diluted to inhibit } \\
\text { Clostridium difficile bacterial growth by } \\
99.9 \% \\
0.15 \% \text { VCO lipolysis inhibits } 50 \% \text { growth } \\
\text { of C. difficile bacteria }\end{array}$ & 47 \\
\hline $\begin{array}{l}\text { Red palm oil } \\
\text { and Palm kernel } \\
\text { oil }\end{array}$ & Fatty acid salt & $\begin{array}{l}\text { Inhibitor zone diameter : } \\
\text { Mixture red palm oil : palm kernel oil } 20 \% \\
\text { pada konsentrasi } 10-50 \% \\
\text { Propionibacterium acne } 8.83-11.73 \mathrm{~mm} \\
\text { Staphylococcus epidermidis } 8.93-10.23 \mathrm{~mm} \\
\\
\text { Red palm oil fatty acid salt showed no } \\
\text { inhibition zone diameter }\end{array}$ & 52 \\
\hline $\begin{array}{l}\text { Algerian seed } \\
\text { oil (Pistacia } \\
\text { lentiscus) }\end{array}$ & $\begin{array}{l}\text { 41.22\% Oleic acid } \\
19.94 \% \text { Linoleic acid }\end{array}$ & $\begin{array}{l}\text { Only provides an inhibition zone of } 1 \mathrm{~mm} \\
\text { towards MRSA bacteria (Methicillin } \\
\text { resistant Staphylococcus aureus) and has } \\
\text { no antibacterial activity towards E. coli and }\end{array}$ & 55 \\
\hline
\end{tabular}


RASĀYAN J. Chem.

Vol. 14 | No. 3 |1680-1698| July - September | 2021

\begin{tabular}{|c|c|c|c|}
\hline & & P.aeruginosa bacteria & \\
\hline $\begin{array}{l}\text { Algerian seed } \\
\text { oil (Opuntia } \\
\text { ficus indica) }\end{array}$ & $\begin{array}{l}12.92 \% \text { oleic acid } \\
\text { Linoleic acid } 55.81 \%\end{array}$ & $\begin{array}{l}\text { Has no antibacterial activity towards } \\
\text { MRSA, E. coli, and P.aeruginosa bacteria }\end{array}$ & 55 \\
\hline $\begin{array}{l}\text { Algerian seed } \\
\text { oil (Argania } \\
\text { spinosa) }\end{array}$ & $\begin{array}{l}28.53 \% \text { Oleic acid } \\
39.10 \% \text { Linoleic acid }\end{array}$ & $\begin{array}{l}\text { Has no antibacterial activity against } \\
\text { MRSA, E. coli, and P.aeruginosa bacteria }\end{array}$ & 55 \\
\hline $\begin{array}{l}\text { Virgin coconut } \\
\text { oil is } \\
\text { hydrolyzed by } \\
\text { enzymes }\end{array}$ & $\begin{array}{l}\text { Lauric acid } \\
\text { Caprylic acid } \\
\text { Capric acid }\end{array}$ & $\begin{array}{l}\text { Formulas inhibit P. aeruginosa, S.aureus, } \\
\text { S.epidermidis, P.acnes after incubated for } \\
12 \text { hours. } \\
\text { The growth of bacteria with VCO } \\
\text { hydrolysis is more active against gram- } \\
\text { negative bacteria (P.aeruginosa) than } \\
\text { gram-positive bacteria (S.aureus). }\end{array}$ & 63 \\
\hline $\begin{array}{l}\text { Fixed oil } \\
\text { (Orbignia } \\
\text { speciosa) }\end{array}$ & $\begin{array}{l}\text { Monounsaturated fatty } \\
\text { acids } \\
\text { Lauric acid }(54.15 \%) \\
\text { Myristic acid }(10.62 \%) \\
\text { Caprylic acid }(9.13 \%)\end{array}$ & $\begin{array}{l}\text { MIC of formulas: E. coli }(\mathrm{MIC} 32 \mu \mathrm{g} / \mathrm{mL}) \\
\text { S.aureus }(\mathrm{MIC} 256 \mu \mathrm{g} / \mathrm{mL}) \\
\text { E. coli ATCC } 25922(\mathrm{MIC} 512 \mu \mathrm{g} / \mathrm{mL})\end{array}$ & 64 \\
\hline $\begin{array}{l}\text { Fixed oil } \\
\text { (Mauritia } \\
\text { flexuosa) }\end{array}$ & $\begin{array}{l}\text { Oleic acid }(72.14 \%) \\
\text { Palmitic acid }(19.3 \%)\end{array}$ & $\begin{array}{l}\text { MIC of formula against S.aureus (MIC } 256 \\
\mu \mathrm{g} / \mathrm{mL} \text { ) } \\
\text { The other strains have MICs of } 512 \mu \mathrm{g} / \mathrm{mL}\end{array}$ & 64 \\
\hline $\begin{array}{l}\text { Schinus } \\
\text { terebinthifolius } \\
\text { essential oil }\end{array}$ & $\begin{array}{l}\text { The composition of fatty } \\
\text { acid (leaves and twigs) } \\
\text { Linolenic acid } 43.14 \% \text { and } \\
24.39 \% \\
\text { Palmitic acid } 20.27 \% \text { dan } \\
21.27 \% \\
\text { Other composition : } \\
\text { terpenoid dan } \\
\text { phenylpropanoids group }\end{array}$ & $\begin{array}{l}\text { Inhibition zone (leaves and twigs) : } \\
\text { E. coli } 10.5 \text { and } 7.83 \mathrm{~mm} \\
\text { S. typhimurium } 10 \mathrm{~mm} \text { and } 8.33 \mathrm{~mm} \\
\text { E. faecium } 31.83 \mathrm{~mm} \text { and } 25.5 \\
\text { S. agalactiae } 27.5 \text { and } 7.67 \mathrm{~mm} \\
\text { Antibacterial activity is derived from } \\
\text { terpenoid and phenylpropanoids }\end{array}$ & 65 \\
\hline $\begin{array}{l}\text { Kleinhovia } \\
\text { hospital leaf oil }\end{array}$ & $\begin{array}{l}\text { Asam palmitat } 17.97 \% \\
\text { Asam linoleat } 8.05 \% \\
\text { Asam oleat } 7.87 \% \\
\text { Asam stearat } 7.79 \%\end{array}$ & $\begin{array}{l}\text { Inhibition zone : } \\
\text { B. subtilis } 19.5 \mathrm{~mm} \\
\text { E. coli } 18.5 \mathrm{~mm} \\
\text { Minimum inhibitory concentration : } \\
\text { B. subtilis } 61.75 \mu \mathrm{g} / \mathrm{ml} \\
\text { B. licheniformis } 60.02 \mu \mathrm{g} / \mathrm{ml} \\
\text { E. coli } 35.75 \mu \mathrm{g} / \mathrm{ml} \\
\text { A. junii } 38.04 \mu \mathrm{g} / \mathrm{ml}\end{array}$ & 66 \\
\hline
\end{tabular}

Fatty acids are classified according to chain length and degree of unsaturation. In biological systems, fatty acids have a number of carbon atoms between 4-28. Fatty acids that have $<8$ carbon chains are referred to as short chain fatty acids, 8-12 carbon chains are called medium chain fatty acids, while $>12$ are long chain fatty acids. ${ }^{38}$ The fatty acid content is very important in oil; it is usually used to determine the identity and purity of the oil. ${ }^{39}$

In unsaturated fatty acids, the increase in double bonds will increase the solubility in water, increasing antibacterial activity. ${ }^{40}$ In antibacterial tests against various bacteria, it is known that unsaturated fatty acids show more significant inhibition than saturated fatty acids by inhibiting biosynthesis. bacterial protein (enoyl-acyl carrier protein reductase/FabI) which in turn will affect the composition of the bacterial cell membrane. ${ }^{41}$

Cacay oil shows antibacterial activity (in vitro) against B. cereus, E. faecalis and S. aureus. Based on the evaluation results, this antibacterial activity is due to the high content of polyunsaturated fatty acids $(58.3 \%) .{ }^{42}$ Similarly, Crotalaria pallida leaf oil which contains fatty acids such as linolenic acid (34.06\%), palmitic acid (24.47\%), linoleic acid (13.50\%) and oleic acid (4.6\%) are known to have 
RASĀYAN J. Chem.

Vol. 14 | No. 3 |1680-1698| July - September | 2021

antibacterial activity against $B$. subtilis $(\mathrm{MIC}=80 \mu \mathrm{g} / \mathrm{ml})$, E. coli $(\mathrm{MIC}=10 \mu \mathrm{g} / \mathrm{ml})$ and Acinetobacter junii $(\mathrm{MIC}=10 \mu \mathrm{g} / \mathrm{ml}){ }^{43}$

Mastic tree oil contained in Pistacia lentiscus L. contains 5 types of fatty acids, namely: oleic acid, palmitic acid, linoleic acid, palmitoleic acid and stearic acid. The extraction method used to obtain mastic tree oil does not significantly affect the fatty acid content contained therein. From the antibacterial test (in vitro), the inhibition zone diameter obtained varies according to the growing site, extraction method, and bacterial strain used. ${ }^{44}$

Crotalaria juncea seed oil (CJSPE) contains 3 main fatty acids components, namely linoleic acid, palmitic acid and stearic acid. Based on the antibacterial test against gram-positive and gram-negative bacteria, it is known that CJSPE has good antibacterial activity against S. aureus, E. coli, K. pneumonia and $S$. flexneri bacteria. However, the antibacterial activity of CJSPE was lower than that of ciprofloxacin $(5 \mu \mathrm{g} / \mathrm{disc})$ which was used as a positive control. ${ }^{39}$

Crotalaria juncea seed oil (CJSPE) contains 3 main fatty acids components, namely linoleic acid, palmitic acid and stearic acid. Based on the antibacterial test against gram-positive and gram-negative bacteria, it is known that CJSPE has good antibacterial activity against S. aureus, E. coli, K. pneumonia and $S$. flexneri bacteria. However, the antibacterial activity of CJSPE was lower than that of ciprofloxacin $\left(5 \mu \mathrm{g} /\right.$ disc) which was used as a positive control. ${ }^{45}$

The hydrophobic group influences the antibacterial activity of saturated fatty acids, the longer the saturated fatty acid chain, the hydrophobicity will increase so that it can reduce the solubility in water. Thus, the hydrophobic group can not interact with hydrophobic protein or lipids on the bacterial cell surface..$^{40,46}$

Saturated fatty acids are a significant component of coconut oil (78.4\%), particularly lauric acid $(38.4 \%){ }^{42}$ Lauric acid is most effective at inhibiting Clostridium difficile bacterial growth. Lauric acid inhibits almost $100 \%$ of Clostridium difficile bacterial growth at a concentration of $1000 \mu \mathrm{M}$. Lauric acid also produces strong inhibition even at a small concentration of $250 \mu \mathrm{M}$, which can reduce bacterial growth by almost $90 \%$ compared to controls. ${ }^{47}$ Lauric acid with a concentration of $15 \%$ and $20 \%$ has a larger zone of inhibition than $0.5 \%$ ciprofloxacin which is tested towards Staphylococcus aureus, Bacillus cereus, Salmonella typhimurium, and Escherichia coli bacteria. ${ }^{48}$

Antibacterial activity of lauric acid depends on the presence of food particles in bacteria culture because gives a site for adsorption of lauric acid into bacteria and inhibits bacterial growth ${ }^{49}$. When lauric acid is digested, then release from triglyceride form and can enter the liver via a portal vein or can be changed into new triglyceride and go to the lymphatic system. ${ }^{38}$ Lauric acid is also a component of fatty acid found in samples of murumuru, palm kernel, babassu, and coconut oil. ${ }^{50}$

Virgin Coconut Oil (VCO) contains 99\% triglycerides with less than $0.2 \%$ free fatty acid. VCO triglycerides can be lipolyzed with lipase and water to form monoglycerides, diglycerides, glycerol, and free fatty acid. Monoglycerides and free fatty acid are reported to have antimicrobial activity while triglycerides, diglycerides, and glycerides have lower antimicrobial activity. ${ }^{47}$

Virgin coconut oil (VCO) does not have antibacterial activity against Clostridium difficile bacteria when added to bacterial culture after grown overnight. However, after VCO is hydrolized with lipase, it shows inhibition of bacterial growth by $99.9 \%$ at a concentration of $1.2 \%$, while at a concentration of $0.15 \%$ VCO lipolysis inhibits $50 \%$ of bacterial growth. ${ }^{47}$ VCO must be metabolized first; therefore, it can release medium chain fatty acid components such as caprylic acid, capric acid, and lauric acid for its antimicrobial activity. From the metabolites mentioned earlier, lauric acid has the greatest antibacterial activity. ${ }^{47}$ Capric acid in VCO can inhibit $90 \%$ of Clostridium difficile bacterial growth at twice a concentration than lauric acid. ${ }^{47}$ Capric acid can inhibit Propionibacterium acnes bacterial growth at a concentration of $1 \mathrm{mM}$, whereas using lauric acid with a concentration of $0.25 \mathrm{mM}$ alone can inhibit Propionibacterium acnes bacterial growth. Caprylic acid in VCO requires five-time concentration to achieve the same bacterial growth inhibition as lauric acid. ${ }^{47}$ Based on these data, it can be said that lauric acid is more potential as an antibacterial than capric acid. ${ }^{51}$

In an antibacterial study of palm kernel oil and red palm oil, which are rich in fatty acid content, fatty acids are extracted first using potassium hydroxide, which will form fatty acid salts. After the antibacterial test against Propionibacterium acnes and Staphylococcus epidermidis, it was found that a 
mixture of red palm oil: palm kernel oil $20 \%$ at a concentration of $10 \%$ had a good antibacterial activity with an inhibition zone diameter of $18.03 \mathrm{~mm} .{ }^{52}$ The antibacterial activity of the mixture comes from the fatty acid salt content of palm kernel oil because after the activity test against red palm oil with a concentration of $10-50 \%$, it does not show any diameter of the inhibition zone. ${ }^{52}$

Chaidir et al stated that the fatty acids and fatty acids methyl esters contained in the microalgae Nannochloropsis oculate had lower antibacterial activity than using positive controls (streptomycin sulfate) against $E$. coli and $S$. aureus bacteria. This is due to the mixing of fatty acids and fatty acids methyl esters with other ingredients. In this study it was also known that the content contained in $N$. oculata microalgae was more sensitive to gram-positive bacteria. ${ }^{53}$

The acid number of oil is an important factor that determines the nutrition of the oil. CJSPE has a high acid value of around 9.66, making this oil unsuitable for use as a nutrient. ${ }^{39}$ It is as same as crotalaria pallida leaf oil which has an acid number of $19.63 .{ }^{43}$

The iodine number is closely related to the concentration of saturated and unsaturated fatty acids of an oil. Coconut oil has a low iodine number due to the high concentration of saturated fatty acids (69.1\%). This contrasts with cacay oil with a high iodine number, indicating that the saturated fatty acid concentration in cacay oil is low $(23.6 \%) .^{42}$ The ratio of saturated / unsaturated fatty acids contained in mastic tree oil is 0.4 , indicating that this oil has a high content of unsaturated fatty acids, which makes this oil more attractive to consume. ${ }^{44}$ Crotalaria pallida leaf oil also contains unsaturated fatty acids which is higher than saturated fatty acids with a ratio of 1.22: $1 .{ }^{43}$ This is different from the fixed oil from Orbignia speciosa which contains a high content of saturated fatty acids $(91.38 \%) .{ }^{54}$ Therefore, the high percentage of unsaturated fatty acids in cacay oil indicates that this oil can be used for food, pharmaceutical and cosmetic products because unsaturated fatty acids have bioactive content for industrial purposes. ${ }^{42}$

\section{CONCLUSION}

The essential oil encapsulation technique can overcome some limitations, including a high percentage of the compound in the encapsulated essential oils compared to the unencapsulated essential oils. In addition, encapsulation also can extend the shelf life of essential oils, as proven by thermogravimetric analysis where the encapsulated essential oils experience longer degradation than unencapsulated essential oils. One of the antibacterial activities of essential oils is due to their content of essential fatty acids. This demonstrates the potential of encapsulation of oils, fatty acids and lipids for antibacterial drugs.

\section{ACKNOWLEDGEMENT}

The authors thank the Directorate of General Higher Education (DRPM DIKTI) for the grant and the Faculty of Pharmacy Universitas Airlangga for research supports.

\section{REFERENCES}

1. S. Siva, C. Li, H. Cui, V. Meenatchi and L. Lin, Ultrasonics-Sonochemistry, 64, 104997 (2020), https://doi.org/10.1016/j.ultsonch.2020.104997

2. G. Zhang, C. Yuan and Y. Sun, Molecules, 23(5), 1126(2018), https://doi.org/10.3390/molecules23051126

3. J. S. F. de Araújo, E. L. de Souza, E. L. de Souza, J. R. Oliveira, A. C. A Gomes, L. R. V. Kotzebue, D. L. da Silva Agostini, D. L. V. de Oliveira, S. E. Mazzetto, A. L. da Silva and M. T. Cavalcanti, International Journal of Biological Macromolecules, 143, 991(2020), https://doi.org/10.1016/j.ijbiomac.2019.09.160

4. M. Dusankova, M. Pummerova and V. Sedlarik, Journal of Microencapsulation, 36(3), 305(2019) https://doi.org/10.1080/02652048.2019.1623337

5. A. F. Hashim, S. F. Hamed, H. A. A. Hamid, K. A. Abd-Elsalam, I. Golonka, W. Musial and I. M. ElSherbiny, International Journal of Biological Macromolecules, 140, 682(2019), https://doi.org/10.1016/j.ijbiomac.2019.08.085

6. K. A. Ghaidani, M. Harwalkar, D. Bhambere, P. S. Nirgude, World Journal of Pharmaceutical Research, 4(8), 516(2015). 
RASĀYAN J. Chem.

Vol. 14 | No. 3 |1680-1698| July - September | 2021

7. C. Prieto and L. Calvo, The Journal of Supercritical Fluids, 128, 227(2017), https://doi.org/10.1016/j.supflu.2017.06.003

8. A.A. Barresi, R. Pisano, D. Fissore, V. Rasetto, S.A. Velardi, A. Vallan, M. Parvis and M. Galan, Chemical Engineering and Processing: Process Intensification, 48, 408(2009), https://doi.org/10.1016/j.cep.2008.05.004C

9. Anandharamakrishnan, C.D. Rielly and A.G.F. Stapley, Dairy Science \& Technology, 90, 321(2010), https://doi.org/10.1051/dst/2010013

10. G. Ozkan, P. Franco, I. De Marco, J. Xiao and E. Capanoglu, Food Chemistry, 272, 494(2019),

11. P. Patil, D. Chavanke and M. Wagh, International Journal of Pharmacy and Pharmaceutical Sciences, 4(4), 27(2012)

12. M. Radünz, H. C. dos Santos Hackbart, T. M. Camargo, C. F. P Nunes, F. A. P. de Barros, J. D. Magro, P. J. S. Filho, E. A. Gandra and A. L. Radünz, E. da Rosa Zavareze, International Journal of Food Microbiology, 330, 108696(2020), https://doi.org/10.1016/j.ijfoodmicro.2020.108696

13. T.A. Comunian, J. Gomez-Estaca, R. Ferro-Furtado, G.J.A. Conceicão, I.C.F. Moraes, I.A. de Castro and C.S. Favaro-Trindade, Carbohydrate Polymers, 150, 319(2016), https://doi.org/10.1016/j.carbpol.2016.05.044

14. C. Peng, S. Q. Zhao, J. Zhang, G. Y. Huang, L. Y. Chen and F. Y. Zhao, Food chemistry, 165, 560(2014), https://doi.org/10.1016/j.foodchem.2014.05.126

15. Y. Yeo, N. Baek and K. Park, Biotechnology and Bioprocess Engineering, 6(4), 213(2001).

16. L. Wang, Y. Liu, W. Zhang, X. Chen, T. Yang and G. Ma, Current Pharmaceutical Design, 19(35), 6340(2013).

17. R. Damayanti, Tamrin, Z. Alfian and Eddiyanto, Rasayan Journal of Chemistry, 13(4), 2483(2020), https://doi.org/10.31788/RJC.2020.1345792

18. A. Gulotta, A.H. Saberi, M.C. Nicoli and D.J. McClements, Journal of Agricultural and Food Chemistry, 62, 1720(2014), https://doi.org/10.1021/jf4054808

19. N. D. Goncalves, F. de Lima Pena, A. Saltoratto, C. Derlamelina, M.C.T. Duarte, A.E.C. Antunes and $\begin{array}{lllll}\text { A.S. Prata, Food } & \text { Research }\end{array}$ https://doi.org/10.1016/j.foodres.2017.03.006

20. T. Bilenler, I. Gokbulut, K. Sislioglu and I. Karabulut, Flavour and Fragrance Journal, 30, 392(2015), https://doi.org/10.1002/ffj.3254

21. I. Simionato, F. C. Domingues, C. Nerín and F. Silva, Food and Chemical Toxicology, 132, 110647(2019), https://doi.org/10.1016/j.fct.2019.110647

22. G. Wadhwa, S. Kumar, V. Mittal and R. Rao, Journal of Food and Drug analysis, 27(1), 60(2019), https://doi.org/10.1016/j.jfda.2018.07.006

23. S. Kumar, Pooja, F. Trotta and R. Rao, Pharmaceutics, 10(4), 169(2018), https://doi.org/10.3390/pharmaceutics10040169

24. M. Hadidi, S. Pouramin, F. Adinepour, S. Haghani and S. M. Jafari, Carbohydrate polymers, 236, 116075(2020), https://doi.org/10.1016/j.carbpol.2020.116075

25. E.A. Soliman, A.Y. El-Moghazy, M.S.M. El-Din and M.A. Massoud, Journal of Encapsulation and Adsorption Sciences, 3(1), 48(2013), https://doi.org/10.4236/jeas.2013.31006

26. Y.F. Wang, J.X. Jia, Y.Q. Tian, X. Shu, X.J. Ren, Y. Guan and Z.Y. Yan, Lebensmittel-Wissenchaft $\begin{array}{lllll}\text { und-Technologie/Food Science } & \text { and }\end{array}$ https://doi.org/10.1016/j.lwt.2017.11.042

27. L. Nurliana, D. Kurniawati, L.A. Kadir, F. Dewi, R. Musta and Nurjana, IOP Conference Series: Earth and Enviromental Science, 465, 012040(2020), https://doi.org/10.1088/1755$1315 / 465 / 1 / 012040$

28. H. M. Zheng, H. B. Li, D. W. Wang and D. Liu, Journal of Food Science, 78(8), N1301(2013), https://doi.org/10.1111/1750-3841.12208

29. Y. Wang, K. Wei, X. Han, D. Zhao, Y. Zheng, J. Chao, J. Gou, F. Kong and C.S. Zhang, Biomolecules, 9(10), 632(2019), https://doi.org/10.3390/biom9100632

30. P. Satyal, J.D. Craft, N.S. Dosoky and W.N. Setzer, Foods, 6(8), 63(2017), https://doi.org/10.3390/foods6080063 
RASĀYAN J. Chem.

Vol. 14 | No. 3 |1680-1698| July - September | 2021

31. S. M. Hosseini, H. Hosseini, M. A. Mohammadifar, A. M. Mortazavian, A. Mohammadi, K. Khosravi-Darani, S. Shojae-Aliabadi, S. Dehghan, and R. Khaksar, International Journal of Biological Macromolecules, 62,582(2013), https://doi.org/10.1016/j.ijbiomac.2013.09.054

32. D.H.A. Baker, M. Al-Moghazy, and A.A.A. ElSayed, Bioorganic Chemistry, 95, 103559(2020), https://doi.org/10.1016/j.bioorg.2019.103559

33. S. Mohtashami, V. Rowshan, L. Tabrizi, M. Babalar. and A. Ghani, Industrial Crops and Products, 111, 226(2018), https://doi.org/10.1016/j.indcrop.2017.09.055

34. N. Li, Z. J. Zhang, X. J. Li, H. Z. Li, L. X. Cui and D. L. He, Journal of the Science of Food and Agriculture, 98(3), 1033(2018), https://doi.org/10.1002/jsfa.8552

35. C. Dima, M. Cotarlet, P. Alexe, and S. Dima, Innovative Food Science and Emerging Technologies, 22, 203(2014), https://doi.org/10.1016/j.ifset.2013.12.020

36. E. Karimi, H. Z. Jaafar, A. Ghasemzadeh, and M. Ebrahimi, Biological research, 48(1), 1(2015).

37. F.M. Dayrit, Journal of the American Oil Chemists' Society, 92(1), 2015, https://doi.org/0.1007/s11746-014-2562-7

38. H.S. Chouhan, A.N.Sahu and S.K. Singh, Journal of Medicinal Plants Research, 5(6), 984(2011)

39. Sutrisno, R. Retnosari, S. Marfu'ah and F. Fajaroh, Key Egineering Materials, 811, 40(2019), https://doi.org/10.4028/www.scientific.net/KEM.811.40

40. C.J. Zheng, J. Yoo, T. Lee, H. Cho, Y. Kim and W. Kim, Federation of European Biochemical Societies, 579(23), 5157(2005), https://doi.org/10.1016/j.febslet.2005.08.028

41. W. Medeiros de Azevedo, L. Ferreira de Oliveira, M. Alves Alcantara, A .M. Tribuzy de Magalhães Cordeiro, K.S. Florentino da Silva Chaves Damasceno, N. Kelly de Arau'jo, C. Fernandes de Assis and F. Caninde de Sousa Junior, PLOS ONE, 15(4), 2020, https://doi.org/10.1371/journal.pone.0232224

42. S. Ukil, S. Laskar, R.N. Roy, Journal of Taibah University for Science, 10(4), 490(2016), https://doi.org/10.1016/j.jtusci.2015.07.001

43. F. Mezni, A. Maaroufi, M. Msallem, M. Boussaid, M.L Khouja and A. Khaldi, Journal of Medicinal Plants Research, 6(39), 5266(2012), https://doi.org/10.5897/JMPR12.473

44. M.B. Sulimah, A.H. Nour, M.M. Yusoff, A.H. Nour, P. Kuppusamy, A.R. Yuvaraj and M.S. Adam, African Journal of Plant Science, 7(7), 300(2013), https://doi.org/10.5897/AJPS2013.1039

45. B. Ouattara, R.E. Simard, R.A. Holley, G.J.P. Piette and A. Begin, International Journal of Food Microbiology, 37, 155(1997), https://doi.org/10.1016/S0168-1605(97)00070-6

46. M. Shilling, L. Matt, E. Rubin, M. P. Visitacion, N. A. Haller, S. F. Grey and C. J. Woolverton, Journal of Medicinal Food, 16(12), 1079(2013), https://doi.org/10.1089/jmf.2012.0303

47. F. O. Nitbani, Jumina, D. Siswanta and E. N. Solikhah, Procedia Chemistry, 18, 132(2016), https://doi.org/10.1016/i.proche.2016.01.021

48. E. Skrivanova, M. Marounek, G. Dlouha and J. Kanka, Letters in Applied Microbiology, 41(1), 77(2005), https://doi.org/10.1111/j.1472-765X.2005.01709.x

49. P. Hovorková, K. Laloučková and E. Skřivanová, Czech Journal of Animal Science, 63(3), 119(2018), https://doi.org/10.17221/70/2017-CJAS

50. W. C. Huang, T. H. Tsai, L. T. Chuang, Y. Y. Li, C. C. Zouboulis and P. J. Tsai, Journal of Dermatological Science, 73(3), 232(2014), https://doi.org/10.1016/j.jdermsci.2013.10.010

51. M. Nainggolan and A.G.S. Sinaga, Rasayan Journal of Chemistry, 14(1), 36(2021), https://doi.org/10.31788/RJC.2021.1415848

52. Z. Chaidir, S. Rahmi, M. Salim, E. Mardiah and H. Pardi, Rasayan Journal of Chemistry, 13(2), 1134(2020), https://doi.org/10.31788/RJC.2020.1325677

53. C.B. Nobre, E.O. de Sousa, J.M.F. de Lima Silva, H.D.M. Coutinho, J.G.M. da Costa, European Journal of Integrative Medicine, 23, 84(2018), https://doi.org/10.1016/j.eujim.2018.09.009

54. F. Brahmi, S. Haddad, K. Bouamara, D. Yalaoui-Guellal, E. Prost-Camus, J. P. P. de Barros, M. Prost, A. G. Atanasov, K. Madani, L. Boulekbache-Makhlouf and G. Lizard, Industrial Crops and Products, 151, 112456(2020), https://doi.org/10.1016/j.indcrop.2020.112456

55. A. N. Badr, H. S. Ali, A. G. Abdel-Razek, M. G. Shehata and N. A. Albaridi, Toxins, 12(12), 748(2020), https://doi.org/10.3390/toxins12120748 
RASĀYAN J. Chem.

Vol. 14 | No. 3 |1680-1698| July - September | 2021

56. A. Sohail, K. S. Abbasi, M. Arif and F. Najam, Pakistan Journal of Agricultural Research, 32(1), 20(2019).

57. B. Başyiğit, H. Sağlam, Ş. Kandemir, A. Karaaslan and M. Karaaslan, Powder Technology, 364, 654(2020), https://doi.org/10.1016/j.powtec.2020.02.035

58. M. Karaaslan, F. Şengün, Ü. Cansu, B. Başyiğit, H. Sağlam and A. Karaaslan, Food Chemistry, 337, 127748(2021), https://doi.org/10.1016/j.foodchem.2020.127748

59. A. C. D. S. Vaucher, P. C. M. Dias, P. T. Coimbra, I. D. S. M. Costa, R. N. Marreto, G. M. Dellamora-Ortiz, O. D. Freitas and M. F. S. Ramos, Journal of Microencapsulation, 36(5), 459(2019), https://doi.org/10.1080/02652048.2019.1646335

60. C. Encina, G. Márquez-Ruiz, F. Holgado, B. Giménez, C. Vergara and P. Robert, Food Chemistry, 263, 283(2018), https://doi.org/10.1016/j.foodchem.2018.05.026

61. R. Musta, L. Nurliana, Risnawati, Damhuri, N.B.A. Prasetya, Rasayan Journal of Chemistry, 14(1), 351(2021), https://doi.org/10.31788/RJC.2021.1415928

62. J. Silalahi, Y. M. Permata and E. D. L. Putra, Asian Journal Pharmaceutical and Clinical Research, 7(2), 90(2014).

63. C. B. Nobre, E. O. de Sousa, J. M. F. de Lima Silva, H. D. M. Coutinho and J. G. M. da Costa, European Journal of Integrative Medicine, 23, 84(2018), https://doi.org/10.1016/j.eujim.2018.09.009

64. A. Emigrou, H. Casablanca, E. Vullet, B. Hanchi and K. Hosni, Journal of Food Science and Technology,55, 1582(2018), https://doi.org/10.1007/s13197-018-3049-6

65. M.C. Dey, R.N. Roy and A. Sinhababu, International Journal of ChemTech Research, 10(3), $378(2017)$

[RJC-6483/2021] 